\title{
Moritz Schlick - ethics from a meta-theoretical perspective
}

\author{
František Mihina
}

\begin{abstract}
Moritz Schlick was the leader of an influential group of scientists, logicians and philosophers. The content of his book "Problems of Ethics" is the application of the method of logical analysis of language to some of traditional ethical problems. Schlick offers many topics in his book Problems of Ethics - what are the motives of human conduct, what is egoism, what is the meaning of "moral", etc. In this article, focus will be on the explanation of only one of many areas of Schlick's ethics - the meta-theoretical perspective describing the main aims of his ethical magnum opus - Problems of Ethics.
\end{abstract}

Keywords: ethics, normative science, philosophy and ethics, egoism, morality, fact and factual

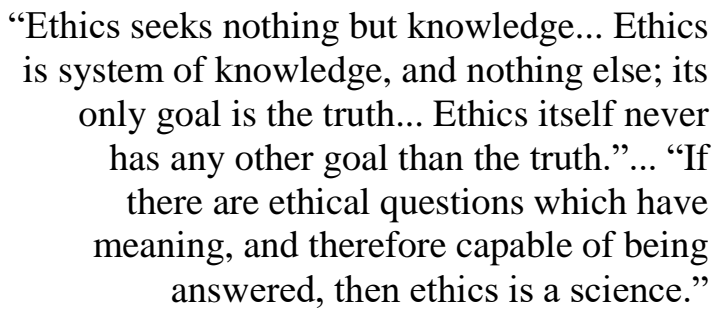

(Schlick, 1939, p. 1)

\section{Introduction}

Philosophical thought at the University of Vienna in the 1920s and 1930s was a significant part of European philosophical initiatives. An influential ideological platform was formed here, which presented an arguable emphasis on the amendment of the character of philosophy. If philosophy is a science, it belongs to the unique set of contemporary knowledge. Is it a time to 'scientify' this set as a whole, i.e. shape it to the required form in all parts of the extensive mosaic of human knowledge? The anti-metaphysical approach gains the character of proscientific reform of all parts of knowledge. ${ }^{1}$ The original strict and universal verificationism rooted in the early Wittgensteinian period has been slowly liberalized. Looking for the meaning of sentences remains dominant, however, the meaning of the sentences themselves should not be strictly conditioned by (often contingent) facts. The problem of modern science is the status of facts which should be the source of any knowledge. Facts within the field of human knowledge are similar, to a lesser extent, to the facts of, for instance, astrophysics.

One of the possible answers was adopted by a group of scientists and philosophers at the University of Vienna, who began to discuss the urgent topic of radical scientism in the 1920s. It was supposed to be realized in the form of paradigmatic transfer of natural-scientific knowledge

\footnotetext{
${ }^{1}$ Schlick strived for the scientification of philosophy and ethics. He was not confident about the fact that physics and natural sciences are enough to explain everything. They can prove a lot, but they cannot do everything. However, it's related even to philosophy - its demand on the explanation of everything has collapsed, it remained only the illusion of some of its representatives. Moreover, evidently it is a misrepresented illusion, harmful for philosophy.
} 
within the field of philosophy, but it was not limited only to philosophy. The initiative towards scientism emphasized the belief that the idea of a unique science is a natural result of its modern evolution. Its main personality was Moritz Schlick (1882-1936), ${ }^{2}$ founder of the so-called Wiener Kreis [Vienna Circle], one of the creators of the philosophy of logical positivism. His program document was Manifest known under the title Wissenschaftliche Weltauffassung: Der Wiener Kreis [Scientific Understanding of the World: Vienna Circle] (August 1929), as it was entitled by the authors. It was published after a mature consideration and deep belief in the need to extend the validity of amendments which happened in science even in the field of philosophy and ethics. How can we help philosophy and ethics if there are no doubts they need help?

Regarding these thoughts, the main area of interest in this paper is the concept developed by Schlick, not of the philosophy itself, but particularly of ethics, thus the philosophy of the human act of knowing through the category of good and evil, free will, through the viewpoint of the spectre of motives resulting in the behaviour of individuals or groups of people. ${ }^{3}$ Did Schlick succeed - and if yes, how - to apply the rigorous epistemological or methodological principles of the Vienna Circle to ethics? Initiators of Vienna scientism were inspired by the alarming growth of metaphysical and theological thought, thus the search for explication matrices in the sphere, where science and critical thinking are not allowed to enter. It's been proven within this viewpoint that problems do not exist in the way they are formulated; they do not get any sense, strictly said. The period of changes has come. New scientific world opinion leans on the assurances of the other type - it recognizes only sentences which are of experiential character regarding their origin, or are translatable to such sentences (according to logical rules of transformation). Beside of them, it recognizes and respects only analytical sentences of logics and mathematics. If philosophy and ethics do not consist neither of the first, neither of the second, we need to change them, as David Hume similarly requested the same almost two centuries ago.

Two levels of knowledge are especially interesting regarding this: a) how and to what extent do we connect ethics with metaphysics; if we eliminate all metaphysical and theological connections, only the conclusions on certain forms of human behaviour, or its deontological $\operatorname{code}^{4}$ remain; b) what is the sensitivity of ethics to the level of language, or is such sensitivity different than in the case of other sciences? Ethics is interested in the character of conclusions which are related to morality; it researches its status, is oriented towards the search of the meaning of sentences which are found in discourses on morality of man and people. Schlick refused to understand ethics as Ontology of good, as the research of metaphysical substance of values - we are not able to provide meaningful answers for traditional scientific practices. There is only one reality and there is only one science seeking knowledge - ethics can be a part of this. If it is focused on the mosaic of utterances on the world of human morality, if it's researched as the facts of human character and human life.

\footnotetext{
${ }^{2}$ This year, there was an anniversary of the death of Moritz Schlick 80 years ago. His remarkable intellectual activity in the field of physics, philosophy and methodology of natural sciences was interrupted violently and tragically - on June $22^{\text {nd }}, 1936$ on the staircase of the former main building of the University of Vienna.

${ }^{3}$ Schlick was interested in ethics in the same way as in scientific philosophy, even though he was less active in his publications in this field. "Vital questions were an inexhaustible source of new reflections for M. Schlick... they were related to topics which interested him since his early years" (Kampits, 1995, p. 163).

${ }^{4}$ However, Schlick refuses the Kantian deontological version of morality. "One of the worst errors of ethical thought lies in his belief that the concept of the moral good is completely exhausted by the statement of its purely formal property, that it has no content to be what is demanded, what should be" (Schlick, 1939, p. 11).
} 
Dismetaphysics is a direct consequence of scientification. Philosophy and ethics based on science means removing their metaphysical scopes and presumptions. As long as we talk about their language, it should meet the demands of the language of science. According to Schlick, it's about scandalous wasting of time, ${ }^{5}$ if we deal with most of the problems which traditionally belong to the field of philosophy and ethics, if we are not looking for new ways of approaches to the search of morality. Schlick is seeking for the support in the renowned David Hume, who was looking for arguments against metaphysics two centuries ago. Vienna scientism began its work in order to set up a mirror to philosophy and ethics. They are and still remain important even in the world of modern thinking - however, it's necessary to show the world of human morality from the perspective and viewpoint of the new scientistic approach.

Philosophy and ethics should keep to their own theories of the fields of reality, which are cognitively taken by science through accepted epistemological and methodological practices, moreover, with an adequate predictive capability enabling the science to be convincing and effective. Said in a different way, the competencies of philosophy and ethics are, in those fields which have been successfully cognitively colonized by science, quite insufficient and their status as an inspirational source is questionable within the contemporary state of knowledge - it's rather the wishful thinking of philosophers and ethicists. If the beginning of the $20^{\text {th }}$ century is characterized by cognitive overheating in the form of the rapid growth of actual knowledge mainly in the field of natural sciences, philosophy and ethics, in comparison with science, are neither able, nor strive to change their own cognitive status - they refuse scientification in Schlick's spirit. This should be changed along with the introduction of logical positivists on the stage of European knowledge.

\section{Operational scope of ethics}

Schlick is one of the founders of logical positivism. If we talk about his understanding of ethics, we find ourselves on uncertain ground if we think of its scientific status. In this understanding, he argues with Bertrand Russell (Russell, 2005, p. 744), according to whom the elimination of ethical reflection from philosophy's circles of interests is scientifically necessary. He was confident that the essence of the scientific status of ethics must be its value neutrality in the meaning of re-orientation of the search exclusively into a discourse where the sphere of morality appears.

The sphere of morality presents the scope where parameters resist its exact determination. Instincts, reason, emotions, interests, relationships, jurisdiction, religion, art, literature enter the game. Its key player is man and we still know relatively little about him/her. Originally, ethics was a discipline which tried to discover the system of God's commandments, tried to set whether certain actions of men are allowed or not in their light. ${ }^{6}$ However, how to understand ethics, if we miss out God, or if we always abstract only from hypothetical metaphysical coherencies? How should ethics look if we strictly request its scientific status? Schlick and his supporters wanted

\footnotetext{
5 "This is the so-called problem of the freedom of the will. Moreover, this pseudo-problem has long since been settled by the efforts of certain sensible persons; and, above all, the state of affairs just described has been often disclosed — with exceptional clarity by Hume. Hence it is really one of the greatest scandals of philosophy that again and again so much paper and printer's ink is devoted to this matter, to say nothing of the expenditure of thought, which could have been applied to more important problems" (Schlick, 1939, p. 143).

${ }^{6}$ This is the way how Otto von Neurath speaks (Neurath, 2006, p. 236).
} 
both - ethics with no God as well as no metaphysics. They were confident that new ethics cannot get along without both.

According to Schlick, morality does not represent a field which is available to scientific understanding. ${ }^{7}$ However, in spite of this, ethics can behave like a science. It's caused by the fact that it will pay attention to the search for discourse which characterizes the field of moral behaviour. It's related to the character of included facts. They don't look like facts which physics or experimental natural science works with. Weight, time, space, speed in physics do not have the same analogy in ethics ${ }^{8}-$ good, justice, freedom, will or intention are totally different facts. For instance, truth as the attributive statement on physical reality is not the same as the truth of human action. "The task of ethics is to explain the moral good. But what sort of thing this good is which we want to explain what the good is?" (Schlick, 1939, pp. 22-23). How the good can become a part of the facts on which science can reflect?

In spite of a dominant life-long orientation on the theoretical problems of natural sciences, methodology of (mainly) inductive sciences and philosophy, Schlick did not stop dealing with topics which "interested him from his [sic] young age" (Kampitz, 1995, p. 163) and belong to the sphere of morality. His interest in ethics and ethical problems was not just superficial, on the contrary. Morality is in every one of us, it presents a significant scope of human behaviour. Humanity or inhumanity is its direct consequence. He was confident that morality is an archetypical $^{9}$ part of man as an individual and human society - it forms the character of human action. It always comes "from itself", is intentional and the whole mosaic of its forms is possible within the standpoint of moral criteria. Looking at the history of ethical thinking shows that ethical emotivism (in a particular sense, the opposite of consequentialism) is revitalized by Schlick's effort in $20^{\text {th }}$ century. David Hume ${ }^{10}$ was its supporter - in brief, ethical emotivism "is set to the request of self-realization, as well as to the principle of joy which is not understood purely hedonistically" (Kampitz, 1995, p. 163). Hume's position in ethics, which is based on his empiricist theory of the mind, is best known for asserting four theses: * Reason alone cannot be a motive to the will, but rather is the "slave of the passions" * Moral distinctions are not derived from reason. * Moral distinctions are derived from moral sentiments: feelings of approval

\footnotetext{
${ }^{7}$ Ethics and philosophy are the same in this sense - their scientification in the form of radical turnover tends to the statements which relevant sciences produce about "reality" in a demanded way. As there are facts, which are interest natural science, there are facts, which we connect to the inner world of man. They are related to the sentences of the whole spectrum of sciences. Ethics as a scientified discipline is interested in them - as philosophy it is interested in sentences, which are the product of sciences of nature.

${ }^{8}$ When Johann Wolfgang Goethe asked, what a binder of the world is, what holds the world together, how it is possible that a human world does not fall apart, he couldn't find the answer. While we ask what holds the space together, what powers hold it together, we know the answer - after Newton's discovery of gravitation, after subsequent discoveries of powers working in the subatomic world, we even do not know why there is gravity, but we are not doubtful at all that it could fall apart without it. But what holds the human world together - if we have to ask the same question - what gravity is it that holds it together as a binder? Everything leans to the fact that such a law of gravity of the human world was the good. But gravity is a physical law, which suggests that its activity is not influenced by us. However, if the good should be something similar in the world of human actions, how to establish it? And what is good for scientific ethics, what is the logical character of their statements?

${ }^{9}$ The problem is that already at this level, thus the level of the basic settings for the life of man, morality is distributed through the entire ax of reasoning limited by the poles of "good-bad" and this state remains in unmodified form till now.

${ }^{10}$ Emotivism claims that moral judgments express the feeling or attitude of approval or disapproval. To say "murder is wrong" is to express one's disapproval of murder. Ethical language is "emotive". So, in one sense, emotivism claims that morality is "subjective".
} 
(esteem, praise) and disapproval (blame) felt by spectators who contemplate a character trait or action.* While some virtues and vices are natural, others, including justice, are artificial. He articulates and defends them within the broader context of his meta-ethics and his ethics of virtue and vice." The one who somehow returned back to Hume's ethical concept was Schlick himself.

At the very beginning of this reflection, it was emphasized that Schlick was aware of the difficulties which came with the transformation of philosophy and ethics to their scientific versions-science was understood only as a part which dominated in the contemporary picture of the world. ${ }^{11}$ However, he was confident that in spite of everything, both are possible to scientify themselves on their behalf. The path could be relatively simple, as he thought; however, it requires meta-theoretical reconstruction or (rather) deconstruction when looking at ethics itself. Its role is not to show what we ought to do within the deontological (Kantian) perspective, but to contribute to the understanding of what we do, how and when we act - on the basis of specific semiotic analysis of the terms which belong to the sphere of morality.

Ethics is generally considered as a part of philosophy. However, philosophy, according to Schlick, is not a science, ${ }^{12}$ thus is not a system of statements which would infer their sense from their relationship to reality, which makes sense for statements made by physics. "[Its] task consists in making clear the content of scientific propositions that is, in determining or discovering their meaning... this activity constitutes the essence of philosophy; there are no philosophical propositions, but only philosophical acts" (Schlick, 1939, p. xiv). Our language, speech, words, which we speak to others are older than ethics, philosophy, physics, etc. Language and speech consist of terms which gained their content over the centuries. In their etymology, there are hidden old meanings we want to understand. Ethics, in Schlick's scientific version, deals with them. Why are they interesting for ethics? Ethics, as an important resource enlightening human behaviour, strives for the understanding of what they have meant exactly and what meaning they acquire today!

And how does Schlick's study "The Problems of Ethics" really look like through the lens of his own methodological and epistemological norms? Does it just consist of what he requires from philosophical texts? Schlick is well aware of his own limits which he sets, in spite of this; however, he does not resign from the task in hand. In his opinion, it's necessary to introduce two temporary notes which enable him to continuously construct the extensive text of "The Problems of Ethics".

Regarding ethics itself, Schlick states its general characteristics. "Every science is, as such, purely theoretical; it seeks to understand; hence the questions of ethics, too, are purely theoretical problems. As philosophers, we try to find their correct solutions, but their practical application, if such is possible, does not fall within the sphere of ethics, If anyone studies these questions in order to apply the results to life and action, his dealing with ethics has, it is true, a practical end; but ethics itself never has any other goal than the truth" (Schlick, 1939, p. 1).

Where is the truth, which philosophers and ethicists are looking for, hidden? And how do they find out they are approaching it? If we look into the past of ethical thinking, we cannot overlook

\footnotetext{
${ }^{11}$ According to the representatives of the Vienna Circle, physics gets closest to the ideal of a real science, which has been represented by epochal discoveries in recent decades; Neurath's principle of physicalism expressed a belief that even other sciences, including philosophy and ethics, should resemble physics in the character of their statements, grounds and possibility.

${ }^{12}$ It is not a science, but nothing stands in the way of become its queen when science itself becomes the object of interest.
} 
that philosopher-ethicists did not manage to avoid the danger of the change from theoretician, philosopher to moralist, researcher to preacher. However, philosopher or ethicist should be neither one nor the other. What is the ethicist as a theoretician dealing with, where are his borders/limits of his interest, what is he talking about, how is he talking if he enters the territory of new ethics? "To what object, or realm of objects, do the questions of ethics belong? These objects have many names, and we use them so often in daily life that one might think we should know exactly what we mean by them. Ethical questions concern morality, or what is morally valuable, what serves as a standard or norm of human conduct, what is demanded of us; or, finally, to use the oldest, simplest word, ethical questions concerns the good" (Schlick, 1939, p. 3 ). In this sense, Schlick follows tradition - said briefly, ethics is interested mainly in the socalled biblical, old-testament good - it is the main object of its interest! ${ }^{13}$ If ethics is transcendental, ${ }^{14}$ as Ludwig Wittgenstein's ${ }^{15}$ early thought had it (and after him even Schlick), how should it look in the light of the requirements of scientification? Moreover, if ethics is transcendental, "ethics cannot be put into words" (Wittgenstein, 1993, p. 6.421). It means that the words we use in discourses on morality are becoming the object of the search of new ethics. From this standpoint, "ethics is the inquiry into the meaning of life, or into what makes life worth living, or into the right way of living" (Munitz, 1981, p. 211). What is the character of the object ethics researches, what can ethics do with it? Schlick's response is brief and clear: "Ethics seeks to understand it, to gain knowledge of it, and would and can under no circumstances do anything else with it. Since ethics is, in essence, [the] theory of knowledge, its task cannot be [sic] produce morality, or to establish it, or call it to life. It does not have the task of producing the good" (Schlick, 1939, p. 3). Differently said, ethics leaves everything as it is. "Where and how, then, is the good of ethics given? We must from the outset be clear on the point that here there is only one possibility, the same that lies before all other sciences. Wherever an instance of the object to be known occurs, a certain mark (or group of marks) must be exhibited which characterizes the thing or event as one of a certain definite kind, thus distinguishing it from all others in a special way. If this were not so we would have no opportunity and no motive to call it by a special name. Every name which is used in discourse for communication must have a meaning capable of being indicated. Thus it is indeed self-evident, and the object of any other science would not be doubted - only in ethics has it sometimes been forgotten" (Schlick, 1939, p. 4). This situation needs to be changed so as not to differentiate ethics from other sciences. Schlick made the decision to go this way. The subject of ethics is not the "good", as it inappropriately appears in traditional

\footnotetext{
${ }^{13}$ When writing "Problems of Ethics", Schlick already knew Wittgeinstein's opinions from his Tractate. There we can find a very important reference to ethics. The meaning of what we consider as (im)moral, we have to look for outside of us. Ethics itself tends to lie "behind" the sphere of human action. "Darum kann es auch keine Sätze der Ethik geben... Es ist klar, daß sich die Ethik nicht aussprechen läßt. Die Ethik ist transzendental" (Wittgenstein, 1993, 6.42; 6.421).

${ }^{14}$ The fact that ethics is transcendental makes it the part of our connection with the mystical, with something we cannot talk-scientifically - about, even though it is ethical in this sense...

${ }^{15}$ In November 1930, the year when Schlick's work "Problems of Ethics" was published, Wittgenstein specified his own concept of ethics, which is mentioned just marginally a few times in Tractate, but fills the background, from which Tractate grows. In his work "L. Wittgenstein. Duty of Genius" R. Monk states following Wittgenstein's words: My whole tendency and I believe the tendency of all men who ever tried to write or talk on [E]thics or $[R]$ eligion was to run against the boundaries of language. The running against the walls of our cage is perfectly, absolutely hopeless. Ethics so far as it springs from the desire to say something about the meaning of life, the absolute good, the absolute valuable, cannot be science. What it says does not add to our knowledge in any sense. But it is document of a tendency in the human mind" (Monk, 1991, p. 277).
} 
philosophical systems - ethics would move within the borders of metaphysics here. Its object is "a good", as it appears in language - ethics is looking for its meanings which are hidden within the layers of language due the long-term use of this word. "But many philosophers see in this a serious difficulty of ethics, indeed the difficulty, and they are of the opinion that the sole task of ethics is the discovery of the definition of good" (Schlick, 1939, p. 5). George Edward Moore (1873-1958) in his Principia Ethica (1903) drew the way of delimitation of ethics as a discipline which behaves like a science. ${ }^{16}$ Right at the beginning of his magnum opus, Moore says: "It appears to me that in Ethics, as in all other philosophical studies, the difficulties and disagreements, of which its history is full, are mainly due to a very simple cause: namely to the attempt to answer questions, without first discovering precisely what question it is which you desire to answer. I do not know how far this source of error would be done away [with], if philosophers would try to discover what question they were asking, before they set about to answer [sic] it; for the work of analysis and distinction is often very difficult: we may often fail to make the necessary discovery, even though we make a definite attempt to do so. But I am inclined to think that in many cases a resolute attempt would be sufficient to ensure success; so that, if only this attempt were made, many of the most glaring difficulties and disagreements in philosophy would disappear" (Moore, 1922, Preface).

Schlick probably knew the text of Moore's study on ethics, ${ }^{17}$ even though he does not mention it those words. Moore, as one of the first, strived for bringing ethics as a theoretical discipline to a trustworthy path of science (as Kant would say) through an intense use of logic and linguistic analysis. There are certain risks hidden in Moore's approach. One of them was that ethics is changing to a quasi-linguistic state here - to a discipline explaining the terms of our language. He characterized the entire former ethics as naturalistic error thereby ethics was not competent to evolve any adequate moral profile of people and their natural discourses. He was interested in meta-ethics, in setting its grounds. Ethics is becoming the interpretation of the content of all moral terms which were formed throughout the centuries. Roughly speaking, even Schlick occurs in this horizon. How should we understand the new ethics? "Rather it would have to be understood as the task of explanation, of complete cognition of the good - which presupposes that the meaning of the concept is already known and then relates it to something else, orders it in more general connections" (Schlick, 1939, p. 6). However, neither not everything is drawn it no ethics in Schlick's version ought to do.

The inner ambition of ethics in its scientific version is not just a pure description of $a$ good, it's not comfortable with the position of descriptor. Ethics, at least according to Schlick, is

\footnotetext{
${ }^{16}$ Moore insists that "good" is indefinable. He defends the objectivity and multiplicity of values, arguing that knowledge of values cannot be derived from knowledge of facts, but only from intuition of the goodness of such states of affairs as beauty, pleasure, friendship and knowledge. In Moore's view, right acts are those producing the most good. However, he also believed that there are only various different sorts of things that are good, including knowledge and aesthetic experience. Moore's Principia Ethica is one of the most influential books from the beginning of the 20th century. From his analytical standpoint, ethics is a science which can be built without traditional support from metaphysics and theology. Resignation is enough to understand ethics as the formulation of ethical norms and values, which - even according to logical positivists, cannot be the task of ethics, if we are to consider it a science. The main method and even non-crossable border, at the same time, should be an analysis of this type of sentences, which have created the frame of ethical theory. If anything else, Moore's reflections significantly stimulated discussions on meta-ethical questions.

${ }^{17}$ It's hard to imagine to have it another way - however, it's not easy to explain why he does not mention it in his work.
} 
creative and discovering. It doesn't reveal, but creates a sense of what we have in our mind in language and speech if we use the word good and its equivalents. "The view according to which the goal of ethics consists of a correct determination of the concept of good could be interpreted as not being concerned with the formulation of the content of the concept, but rather with giving it content... it would mean that the philosopher made, or created, the concept of the good, while without him the word good merely existed. He would of course invent it quite arbitrarily... However, it would be quite absurd to demand of ethics nothing but the arbitrary establishment of the meaning of a word; that would be no achievement at all" (Schlick, 1939, p. 7). However, the reformulation of the content of the term good is not the ultimate goal of ethics, "it cannot be regarded as anything but a mere preparation... this preparation is not be neglected" (Schlick, 1939 , p. 8). Thus, what is the meaning of ethics, if conceptual (semiotic, logic...) analysis of the good is not ultimate, but only a preparatory phase of its real activity?

\section{Ethics as a normative science}

Schlick's study Fragen der Ethik [Questioning Ethics] was published at the time of logical positivism. The author asks, besides everything else, for the status of ethics - he is interested whether ethics is a normative science or science about reality/matter. What is the reality of ethics as a science? Even these two types of sciences - normative sciences and sciences about reality, have to meet the criteria which even other sciences meet all together and every one of them individually. And - in this sense, it's not possible to oppose them to themselves. Logical positivists preferred opinion that ethics is or ought to be built as a normative science. It doesn't say, what the reality of human behaviour and its motivation is, it's not its description (for instance, that's the role of psychology or sociology, politics).

In the researched context, we are interested in Schlick's arguments in favour of opinion that "ethics is a normative science" (Schlick, 1939, p. 17). This idea is not a new one, but on the contrary, its acceptance is connected to Kantian heritage. ${ }^{18}$ What does it really mean that ethics is a) a science and b) a normative science? The status of science is based on the fact that the materials which a scientist works with are the facts - in our case, facts of human nature. Ethics furnishes a justification for these facts in a relative-hypothetical way, not absolutely. "It is never able to do more than to discover the rules of the judgment, to read them from the facts before; the origin of norms always lies outside and before science and knowledge" (Schlick, 1939, p. 18). Ethics cannot and is not able to do more than its own resources enable it to. Ethics doesn't say what the good is, ethics tells us what good actually means; it can never tell us what good must or should mean. If we talk about ethics as a normative science, Schlick's position is "we see that this theory of norms affords nothing more than the discovery of the meaning of the concept of good. There is no question in it of a real explanation of good; it offers ethics only the object which is to be explained" (Schlick, 1939, p. 23).

The explanation is reduction to something more general, the moral good could be shown to be a special case of a more general kind of good. Ethics seeks causal explanation. The word good is an abstraction, but is "connected with actual mental occurrences and separate acts of this sort are quite capable of explanation, that is, can be reduced to one another" (Schlick, 1939, p. 24). By

\footnotetext{
18 "In modern philosophy, ever since Kant, the idea has repeatedly appeared that ethics as normative science is something completely different from factual sciences... But this manner of opposing normative and factual sciences is fundamentally false... Ethics must simply recognize facts of human nature; even as a normative science, science can do no more than explain" (Schlick, 1939, p. 17).
} 
logical-linguistic analysis of the term 'equipment of human morality', normative ethics strives to transform particular terms using the reductive method to the level of having their factual status clear which is characteristic for a scientific approach. The normativity of ethics does not change "the state of a matter", it changes the way of their language/linguistic symbolic image which is available to our understanding. ${ }^{19}$

\section{Ethics as factual science}

The facts which ethics operates with, creates norms, values, motives of human behaviour - they are derived from the human character and the life of people. "No result of ethics can stand in contradiction to life; ethics cannot declare as evil or false those values which lie at the foundation of life; its norms cannot demand or command anything that is in real opposition to those final norms recognized by life. Where such opposition occurs, it is a sure sign that the philosopher has misunderstood his problem, and has failed to solve it; that he has unwittingly become a moralist, that he feels uncomfortable in the role of knower and would prefer to be a creator of moral values" (Schlick, 1939, p. 20). In such a case, the philosopher or ethicist does not behave like a scientist - a scientist is even neither a moralist, nor a visionary, a scientist can see just what he/she is able to express in language which is understandable even to others. This platform, which the ethicist is based on, is the real life of people, the motives of their behaviour, disagreement with the idealization of human character. "There could be no real opposition between the meaning of the word good that is actually accepted in life, and the meaning found by philosophers" (Schlick, 1939, p. 20). The language we use and the reason through which we reflect on moral facts of human life, are not perfect as tools - if we are able to understand their imperfections and limitations, we can reduce or limit the number of errors.

"The ultimate valuations are facts existing in human consciousness, and even if ethics were a normative science it would not cease, because of this, to be a science of facts. Ethics has to do entirely with the actual; this seems to me to be the most important of the propositions which determine its task" (Schlick, 1939, p. 20). The facts of ethics are ultimate valuations - the ethicist considers them as facts, they are the scope of his reflections. However, ethics is a normative science - as such, it sets hierarchical order of rules, "[in] which all acts and attitudes and characters would possess a definite place with respect to their moral value" (Schlick, 1939, p. 22). Ethics becomes the theory of norms, rules which it actually finds in motives of human behaviour, it doesn't judge people, it explains the character of their actions. Ethics cannot fill this role by itself - but it accepts that truth. "If we decide that the fundamental question of ethics, "Why does man act morally?" can be answered only by psychology, we see in this no degradation of, nor injury to, science, but a happy simplification of the word-picture. In ethics we do not seek independence, but only the truth" (Schlick, 1939, p. 30).

\section{Conclusion}

According to Rudolf Carnap, a close co-worker of Schlick's, this founder did not experience the appreciation that he would deserve (Collinson, 1987, p. 276). It was maybe caused by his early

\footnotetext{
${ }^{19}$ For instance, the sentence, which is similar to a sentence found within normative ethics, "[E]very moral agent has special duties towards his relatives and thus ought to perform the good" (Gluchman, 1997, p. 94) is purely deontological. Normative ethics, in this case, would not doubt the supposed duty of "moral agent" to do good, but would present the indefiniteness of the interpretation of the word "good" itself. If we transform the word "good" to the level of facts, we are not able to say what exactly the moral agent ought to do.
} 
tragic death, maybe the fact that logical positivism was a collective work and Schlick was only one of its creators. However, in spite of this, Schlick's "footprint" in philosophy is consistently visible and it's likewise true even in his ethics and the "problems" he tries to reflect in a nonstandard way.

František Mihina is a Professor of Philosophy at the University of Prešov. He published and edited the following books: Charles Sanders Peirce: Credo ut intelligam (Prešov: Universum, 2014); Idiografia vývinu amerického filozofického myslenia [Idiography of the American Philosophical Thinking] (Prešov: FF UPJŠ, 1993); Logický pozitivizmus [Logical Positivism] (Bratislava: Iris, 2006); Charles Sanders Peirce: From the Philosopher's Heritage, co-editor with M. Derajová (Bratislava: Iris, 2015); Pragmatizmus: Malá antológia filozofie 20. storočia [Pragmatism: An Anthology of the Philosophy of the 20 ${ }^{\text {th }}$ Century] (Bratislava: Iris, 1998) and others.

\section{Corresponding author:}

František Mihina, Institute of Philosophy, University of Prešov, 17 Novembra 1, SK-080 78 Prešov (Slovakia)

Email:mihina@unipo.sk

\section{References}

CARNAP, R. (1968): Filozofia a logická syntax [Philosophy and logical syntax]. In: J. Bodnár, P. Cmorej, I. Hrušovský \& A. Riška (eds.): Antológia z diel filozofov. Logický pozitivizmus a filozofia prirodných vied [Anthology from the works of philosophers: Logical positivism and the philosophy of natural sciences]. Bratislava: Pravda, pp. 265-307.

COLLISON, D. (1987): Piecdziesieciu wielkich filozofow [Fifty great philosophers]. Poznań: Zysk.

GLUCHMAN, V. (1997): Človek a morálka [Man and morality]. Brno: Doplněk.

KAMPITS, P. (1995): Malé dějiny rakouské filozofie [Short history of Austrian philosophy]. Praha: Concordia.

MONK, R. (1991): Ludwig Wittgenstein: The Duty of Genius. London: Vintage. MOORE, G. E. (1922): Principia Ethica. Cambridge: Cambridge University Press. MUNITZ, M. K. (1981): Contemporary Analytic Philosophy. New York: Macmillan.

NEURATH, O. (2006): Sociológia z pohl'adu fyzikalizmu [Sociology from the perspective of physicalism]. In: F. Mihina, T. Sedová \& M. Zouhar (eds.): Logický pozitiviumus [Logical positivism]. Bratislava: Iris, pp. 219-247.

SCHLICK, M. (1939): Problems of Ethics. New York: Prentice-Hall.

RUSSELL, B. (2005): Jazyk a poznanie [Language and knowledge]. Bratislava: Kalligram.

WITTGENSTEIN, L. (1993): Tractatus logico-philosophicus. Praha: Oikoymenh. 